\title{
Exotic hornfelses from the Land's End aureole
}

SIR,-In a recent paper on the cordierite-anthophyllite hornfelses of the Land's End aureole, Chinner \& Fox (1974) argue that they have been derived isochemically, from previously degraded basaltic material, during subsequent contact metamorphism. I would agree that the presence of complex multiphase assemblages and small scale compositional domains does suggest that the parental material might have been chemically heterogeneous prior to contact metamorphism. In view of the work by Vallance (1967) on similar rocks, this mode of derivation seems more plausible than (long-range) internal Fe-Mg metasomatism (Tilley, 1935; Floyd, 1965).

While accepting the isochemical development of the cordierite-anthophyllite hornfelses, I would like to discuss the nature of the parental material and also to broaden the discussion to include the calc-silicate hornfelses which are intimately associated with the hornblende hornfelses (greenstone hornfelses). It could be argued that these $\mathrm{Ca}$ hornfelses represent the isochemical derivatives of calciferous portions of the degraded basaltic material. Thus both the $\mathrm{Mg}-\mathrm{Fe}$ hornfelses (anthophyllite- and cummingtonitebearing) and the $\mathrm{Ca}$ hornfelses (calc-silicate-bearing) could logically be derived from different portions of the previously degraded basalt. Although attractive, this scheme presents problems as will be discussed below.

Table 1 shows averaged chemical data for the different hornfelsic types of initially magmatic origin in the aureole (Tilley, 1935; Floyd, 1965; and unpublished data by Floyd). The actinolite hornfelses are the commonest contact metamorphic products of both dolerite sills and pillow lavas, and in the former case may contain relict clinopyroxene and exhibit sub-ophitic texture. Relative to this group, the $\mathbf{M g}-\mathrm{Fe}$ hornfelses are enriched in $\mathrm{Mg}$ and $\mathrm{Al}$, and depleted in $\mathrm{Si}, \mathrm{Ca}, \mathrm{Sr}$ and $\mathrm{Cu}-$ features not dissimilar to that recorded during basalt degradation and spilitization (Melson \& Van Andel, 1966; Cann, 1969; Vallance, 1969). It is interesting to note that while the anthophyllite hornfelses show a marked increase in $\mathrm{Mg}$ and $\mathrm{Fe}$, the $\mathrm{Cr}$ and $\mathrm{Ni}$ values are very low. If these hornfelses had been formed by metasomatism then it might be expected that the ferromagnesian trace elements would have also been enriched during this process. It seems more likely that they were lost during early degradation and excluded from the minerals (particularly chlorite) that formed. In this context Melson, Thompson \& van Andel (1968) have reported that $\mathrm{Cr}, \mathrm{Ni}$ and $\mathrm{Co}$ are marginally lower in submarine spilitic rocks relative to the fresh basalt parents. Similarly both Cu (Floyd, 1968) and U (Wilson \& Floyd, 1974) are very low relative to the other hornfelses and reflect mobilization at some early stage and/or during contact metamorphism. The $\mathrm{Ca}$ hornfelses are depleted still further in $\mathrm{Si}$ and have low $\mathrm{Al}, \mathrm{Mg}, \mathrm{Ba}, \mathrm{Co}$ and $\mathrm{Ni}$ values. They are also more highly oxidised than any of the other hornfels groups. Although $\mathrm{Ca}$ is characteristically high there is not a sympathetic increase in Sr.

I would now like to discuss the most likely parental material and its generation prior to the development of the $\mathrm{Mg}$ and Ca hornfelses. Due to lack of suitably degraded material within the aureole, this will necessitate reference to variably altered basic magmatic rocks (dolerites and pillow lavas) outside.

Figure 1 shows that with regard to $\mathrm{Ca}$ and $\mathrm{Mg}$ there is a 'continuum' of compositions from the calc-silicate hornfelses through to the anthophyllite hornfelses. The negative relationship between $\mathrm{Ca}$ and $\mathrm{Mg}$ in these hornfelses (excluding the metamorphic actinolite hornfelses) is similar to that for degraded 'basalts' composed (for the sake of argument) of variable mixtures of epidote and chlorite - two very common alteration products. Allowing for the presence of other secondary products the hornfels continuum could be explained in terms of the variable distribution of principally epidote and chlorite, which on contact metamorphism produced the extreme $\mathrm{Ca}$ and $\mathrm{Mg}$ hornfelses, as well as the hornblende hornfels suite.

Geol. Mag. 112 (3), 1975, pp. 315-319. Printed in Great Britain. 
Table 1. Average chemical composition of various hornfelses from the Land's End aureole. Oxides in weight $\%$ and trace elements in p.p.m.

\begin{tabular}{lccccc}
\hline & $\begin{array}{c}\text { Actinolite } \\
\text { hornfelses }\end{array}$ & $\begin{array}{c}\text { Hornblende } \\
\text { hornfelses }\end{array}$ & $\begin{array}{c}\text { Cumming- } \\
\text { tonite } \\
\text { hornfelses }\end{array}$ & $\begin{array}{c}\text { Antho } \\
\text { phyllite } \\
\text { hornfelses }\end{array}$ & $\begin{array}{c}\text { Calc- } \\
\text { silicate } \\
\text { hornfelses }\end{array}$ \\
\hline $\mathrm{SiO}_{2}$ & 48.03 & 43.27 & 44.57 & 44.38 & 37.91 \\
$\mathrm{TiO}_{2}$ & 2.60 & 2.40 & 2.54 & 2.28 & 2.86 \\
$\mathrm{Al}_{9} \mathrm{O}_{3}$ & 14.13 & 15.22 & 15.74 & 17.43 & 11.88 \\
$\mathrm{Fe}_{2} \mathrm{O}_{3}$ & 1.10 & 2.30 & 1.41 & 2.51 & 4.45 \\
$\mathrm{FeO}_{\mathrm{MnO}}$ & 10.63 & 10.15 & 10.35 & 13.58 & 8.09 \\
$\mathrm{MgO}$ & 0.20 & 0.26 & 0.17 & 0.11 & 0.58 \\
$\mathrm{CaO}$ & 8.37 & 8.98 & 11.23 & 12.08 & 6.42 \\
$\mathrm{Na}{ }_{9} \mathrm{O}$ & 7.93 & 12.01 & 6.42 & 2.16 & 23.56 \\
$\mathrm{~K}_{2} \mathrm{O}$ & 2.67 & 1.95 & 3.02 & 2.34 & 0.30 \\
$\mathrm{P}_{2} \mathrm{O}_{5}$ & 1.96 & 2.08 & 1.74 & 0.87 & 0.64 \\
$\mathrm{H} \mathrm{O}^{+}$ & 0.38 & 0.57 & 0.57 & 0.33 & 0.89 \\
$\mathrm{No}$ of samples & 2.00 & 1.62 & 2.38 & 2.18 & 1.94 \\
$\mathrm{Bfiz}$ & 8 & 26 & 17 & 7 & 4 \\
$\mathrm{Co}$ & 140 & 253 & 224 & 146 & 75 \\
$\mathrm{Cr}$ & 38 & 41 & 47 & 44 & 25 \\
$\mathrm{Cu}$ & 152 & 192 & 231 & 56 & 100 \\
$\mathrm{Ga}$ & 157 & 72 & 49 & 31 & 102 \\
$\mathrm{Ni}$ & 24 & 21 & 22 & 24 & 23 \\
$\mathrm{Sc}$ & 109 & 138 & 106 & 29 & 78 \\
$\mathrm{Sr}$ & 22 & 12 & 13 & 33 & 1.2 \\
$\mathrm{~V}$ & 230 & 196 & 149 & 80 & 184 \\
$\mathrm{Y}$ & 228 & 200 & 256 & 263 & 179 \\
$\mathrm{Zr}$ & 33 & 37 & 33 & 30 & 45 \\
$\mathrm{No}$ & 142 & 333 & 295 & 194 & 276 \\
of samples & 8 & $22 *$ & 11 & 5 & 5 \\
\hline
\end{tabular}

* Less for some trace elements-

What evidence outside the aureole is there for such degraded rocks? In massive sills low-grade hydrous alteration is common and takes two forms: (a) development of epidote-chlorite-actinolite (e.g. Cudden Point sill, S. Cornwall; Floyd \& Lees, 1972) and (b) development of chlorite-calcite (e.g. Ryecroft sill, Devon; Morton \& Smith, 1971). As seen from Figure 1 the chemical variation shown by these sills is not sufficient to develop the anthophyllite or calc-silicate hornfelses directly by isochemical metamorphism. Contact metamorphism of the altered Cudden Point sill could however, account for some of the variation seen in the hornblende and cummingtonite hornfelses.

Pillow lavas in Cornwall (e.g. at Pentire Point and Mullion Island) are mainly composed of an albite-chlorite-calcite-Fe oxide matrix with variable chlorite, calcite and silica vesicular infillings. The field (Fig. 1) of pillow lava rims (unpublished data by Floyd which contain the highest percentage of matrix and amygdaloidal chlorite, are again relatively low in $\mathrm{Mg}$ and high in $\mathrm{Ca}$ to be the direct isochemical equivalents of the anthophyllite hornfelses. However, on extracting the $\mathrm{Ca}$ equivalent to the $\mathrm{CO}_{3}$ content of these samples (i.e. removing secondary calcite) and replotting the results, a similar level of $\mathrm{Ca}$ to that in the anthophyllite hornfelses is obtained. It will be noted that only two pillow lava selvages (representing a small portion of the total pillow only) from Mullion Island (Vallance, 1965) have directly comparable $\mathrm{Ca}$ and $\mathrm{Mg}$ contents to the anthophyllite hornfelses. Other than invoking the $\mathrm{Mg}$ metasomatism of the 'decalcified' pillows, how can they attain the required $\mathrm{Mg}$ content? One main difference between 


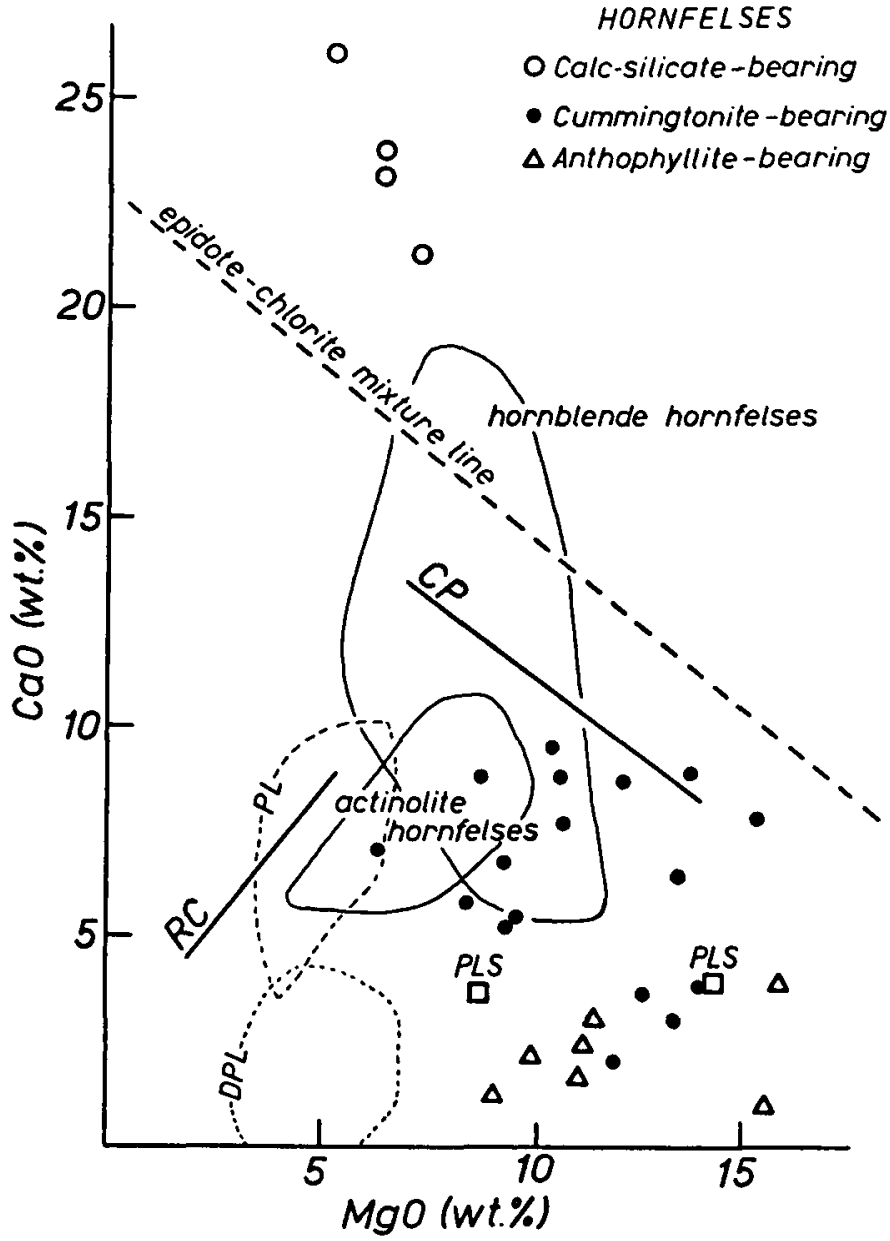

Figure 1. Comparison of the distribution of $\mathrm{Ca}$ amd $\mathrm{Mg}$ in various Land's End aureole hornfelses with altered dolerite sills (CP, Cudden Point; RC, Ryecroft) and pillow lavas (PL, pillow lava field; DPL, 'decalcified' pillow lava field; PLS, pillow lava selvages, Mullion Island) from outside the aureole. Epidote-chlorite 'mixture line' represents the distribution of $\mathrm{Ca}$ and $\mathrm{Mg}$ in variable mixtures of epidote and chlorite in altered rocks entirely composed of these two minerals.

the pillow lavas and sills outside the aureole is that they have suffered relatively little shearing compared to the $\mathrm{Mg}, \mathrm{Ca}$ and some hornblende hornfelses developed within the aureole. As the pillows studied here have 'retained' high $\mathrm{Ca}$ contents (largely due to secondary calcite), extensive shearing and penetration by fluids might remove the $\mathrm{Ca}$ in solution and concentrate the chlorite-rich portions into zones sufficiently high in $\mathrm{Mg}$. Shearing, in this case, is considered an important pre-requisite for the isochemical development of the anthophyllite hornfelses in particular. Similar arguments could be applied to the chlorite-rich marginal zones of some sheared dolerite sills which, although having the required $\mathrm{Mg}$ content, would need to lose considerable $\mathrm{Ca}$. In a few rare cases anthophyllite can be seen in unsheared aureole rocks (e.g. at base of Carn Moyle cliff), although 
here it clearly replaces or is later than the metamorphic hornblende in the parent hornfels.

With regard to the $\mathrm{Ca}$ hornfelses, mineralogical replacement textures indicate that they are metasomatic, as calciferous minerals replace previously developed hornblende hornfelses (Floyd, 1965). In these hornfelses relict hornblende is replaced by diopside and grossularite, and diopside may occur within large garnet porphyroblasts. Strongly zoned epidote is sometimes associated with garnet in lenses. Prograde clinozoisite and sphene are found within large poikiloblasts of zoned axinite, which may itself be replaced by calcite. Plagioclase developed in diopside-rich areas is labradorite rather than the andesine of the adjacent hornblende hornfelses. In general there is a progressive sequence of calciferous mineral replacement among the $\mathrm{Ca}$ hornfels suite. It seems likely that the $\mathrm{Ca}$ required was mobilized during the extensive shearing phase and metasomatized the contact hornfelses during metamorphism.

Due to the 'retention' of moderate $\mathrm{Ca}$ contents by the degraded rocks outside the aureole and also the mineralogical replacements observed within the aureole, the above scheme seems more likely than a direct isochemical metamorphism of the Ca-rich portions of previously degraded basalts for the generation of the Ca hornfelses. This does not rule out the isochemical development of some hornfelses (e.g. the more Ca-rich hornblende hornfelses) from degraded basalts composed of a mixture of $\mathrm{Ca}-$ and $\mathrm{Mg}$ rich materials.

I therefore propose the following general scheme for the development of both the $\mathrm{Mg}$ and $\mathrm{Ca}$ hornfelses.

1. Low-grade hydrous degradation of basaltic pillow lavas and sills. In this case 'retaining' moderate levels of $\mathrm{Ca}$ due to the development of secondary calcite and/or epidote.

2. Extensive localized shearing prior to granite emplacement (greenstone shear foliation dips away from contact all round granite).

3. Contact metamorphism and variable removal of $\mathrm{Ca}$ in solution. Non-sheared, partly degraded basalts are contact metamorphosed to actinolite and hornblende hornfelses depending on grade.

(a) Chlorite-rich areas are isochemically metamorphosed to anthophyllite hornfelses. (If Si-poor and Al-rich, spinel and diaspore also developed).

(b) Chlorite-epidote-calcite areas isochemically metamorphosed to hornblende and cummingtonite hornfelses with variable $\mathrm{Ca}$ content, depending on the initial chlorite to epidote +calcite ratio. (If $\mathrm{Si}$-poor, spinel also developed).

4. Completely mobilized $\mathrm{Ca}$ progressively metasomatizes earlier hornfelses to jroduce the calc-silicate hornfels suite.

The range of exotic hornfelsic types thus depends on the relative mobility of the $\mathrm{Ca}$ ion within variably degraded basaltic rocks during contact metamorphism. late $\mathrm{Ca}$ migration is also indicated by the development of grossularite-clinozoisite, grossularitetourmaline and epidote-axinite-sodic hornblende veins within the hornfelses.

Some mineralogical features of the cordierite-anthophyllite hornfelses, not mentioned by Chinner \& Fox (1974), may indicate minor (possibly very local) movement of $\mathrm{Mg}$ and Fe. (a) Cordierite porphyroblasts replace earlier labradorite and enclose strings of stellate anthophyllite (Tilley, 1935). (b) Anthophyllite appears to be of two generations in the finer-grained $\mathrm{Mg}$ hornfelses: early small stellate clumps (often set in a very finegrained biotite matrix) and also large prisms (sometimes biotitized) that grow across the main foliation. (c) In a few cases anthophyllite appears later than spinel, growing across and replacing large grains. (d) Large clinochlore prisms appear to pre-date associated anthophyllite and also replace an early phlogopitic biotite which occurs as small optically continuous relicts within it. The mineral paragenesis appears complex with replacement and close association of early and late phases. In this context the equilibrium between spinel, cordierite and anthophyllite margins (Chinner \& Fox, 1974, p. 404) probably took place at a late stage when exchange with circulating fluids was possible. 


\section{References}

Cann, J. R. 1969. Spilites from the Carlsberg Ridge, Indian Ocean. J. Petrology 10, 1-19.

Chinner, G. A. \& Fox, J. S. 1974. The origin of cordierite-anthophyllite rocks in the Land's End aureole. Geol. Mag. 111, 397-408.

Floyd, P. A. 1965. Metasomatic hornfelses of the Land's End aureole at Tater-du, Cornwall. J. Petrology 6, 223-45.

Floyd, P. A. 1968. Distribution of $\mathrm{Cu}$ in the basic hornfelses of the Land's End aureole, Cornwall and other chemically similar rocks. Geochim. cosmochin. Acta 32, 879-96.

Floyd, P. A. \& Lees, G. J. 1972. Preliminary petrological and geochemical data on the Cudden Point greenstone. Proc.Ussher Soc. 2, 421-3.

Melson, W. G. \& van Andel, J. H. 1966. Metamorphism in the Mid-Atlantic Ridge, $22^{\circ}$ N. latitude. Marine Geol. 4, 165-86.

Melson, W. G., Thompson, G. \& van Andel, T. H. 1968. Volcanism and metamorphism the Mid-Atlantic Ridge, $22^{\circ}$ N. latitude. J. Geophys Res. 73, 5925-41.

Morton, R. D. \& Smith, D. G. W. 1971. Differentiation and metasomatism within a Carboniferous spilite-keratophyre suite in S.W. England. Spec. Paper Mineral. Soc. Japan, 1, 127-33.

Tilley, C. E. 1935. Metasomatism associated with the greenstone-hornfelses of Kenidjack and Botallack, Cornwall. Mineralog. Mag. 24, 181-202.

Vallance, T. G. 1965. On the chemistry of pillow lavas and the origin of spilites. Mineralog. Mag. 34, 471-81.

Vallance, T. G. 1967. Mafic rock alteration and isochemical development of some cordierite-anthophyllite rocks. J. Petrology 8, 84-96.

Vallance, T. G. 1969. Spilites again: some consequences of the degradation of basalts. Proc. Linn. Soc. N.S.W. 94, 8-51.

Wilson, I. R. \& Floyd, P. A. 1974. Distribution of uranium in the Land's End granite and aureole, and various greenstones from Cornwall. Proc. Ussher Soc. (In the press).

P. A. FLOYD

Department of Geology

University of Keele

Staffordshire, ST5 5BG

England

29th October 1974

\section{Slickensides and slickenlines}

SIR - A recent article (Weaver, 1974) prompts me to draw attention to the current confusion concerning the meaning of the term slickenside. The International Tectonic Dictionary (Dennis, 1967, p. 136) gives a definition which indicates that a slickenside is a polished surface (i.e. a planar structure). Unambiguous definitions with the same meaning are given by Billings $(1972$, p. 201$)$, Spencer $(1969$, p. 70$)$ and Stozes \& White $(1935$, p. 191). Such a definition is obviously implied by the use of the word side as part of the term, and is in agreement with the original meaning (cf. Conybeare \& Phillips, 1822 , p. 348 ; Lyell, 1874 , p. 64). Other geological dictionaries concur with this meaning of the term (American Geological Institute, 1957, p. 269; Challinor, 1967; p. 231; Schieferdecker, 1959, pp. 111, 173) as do some published descriptions (e.g. Lindström, 1974). It is generally accepted that two other types of structure are commonly associated with such surfaces, namely linear structures in the form of striations or grooves, and minute step structures at a high angle to the lineations. These features are believed to reflect the displacement direction on the surface.

However, it is common in the more recent literature to find the term slickenside used

Geol. Mag. 112 (3), 1975, pp. 319-322. Printed in Great Britain. 